\title{
Литература:
}

1. Гарбовский Н.К. Теория перевода: Учебник. М.: Изд-во Московского университета, 2004. 544 с.

2. Золотова Г.А. О роли семантики в членении предложения // Вопросы истории языка и современного состояния. М.: Высшая школа, 1998. C. $142-162$.

3. Слюсарева Н.А. Гиперсинтаксический уровень языка в лингвистическом членении текста // Предложение и текст в семантическом аспекте. Калинин: КГУ, 1993. С. 93-111.

4. Тюленев С.В. Теория перевода: Учебное пособие. М.: Гардарики, 2004. $336 \mathrm{c}$.

5. Черняховская Л.А. Перевод и смысловая структура. М.: Международные отношения, 1976. 262 с.

6. Fowles J. The Ebony Tower. London: Granada publishing, 1974. 115 р. Фаулз Дж. Башня из черного дерева // ИЛ, 1979. № 3. С. 115-185. Перевод с англ. К.Чугунова.

DOI https://doi.org/10.30525/978-9934-26-110-7-64

\section{TRANSLATION OF JURIDICAL TERMS IN AMERICAN NOVELS}

\author{
Mosiyevych L. V. \\ Candidate of Philological Sciences, \\ Associate Professor at the Department of General Education \\ Institute of Education and Science in Engineering \\ Zaporizhzhia National University \\ Zaporizhzhia, Ukraine
}

The main application area of terminological vocabulary is official and scientific style. However, entering the various genres of fiction, terminological vocabulary acquires expressive stylistic functions. In our paper, we will use definition of a term provided by L'Homme: «the term is a word or a phrase that is used to express a concept, accepted in a relevant professional field and used in specific conditions» [4, p. 55]. In recent years, the Ukrainian linguists Bilozerska, Voznenko, \& Radetska [1], Karaban [3] etc. have been actively working out issues of terminology translation, standardization of national terminology and the compilation of terminology dictionaries. Despite the narrow specialization of most terms, their use in fiction does not interfere with the reader's perception [2, p. 198]. 
The main purpose of our study is to analyze translation of juridical terms into Ukrainian in the novels «The Minds of Billy Milligan» by D. Keyes, «Hearts of Three» by D. London, P. Beatty «The Sellout». «The Minds of Billy Milligan» is a documentary about Billy Milligan, a man who suffers from multiple illnesses and is accused of numerous crimes, that is why the usage of legal terms in it is quite relevant.

Legal terms, mainly, fill the novel by D. Keyes in the first part. Mostly they are translated into Ukrainian through:

1) Equivalent translation: suspects - підозрювані, rаре - згвалтування, kidnapping - викрадення, robbery - пограбування, felony cases - тяжкі злочини; warrant for arrest - ордером на арешт, a search warrant-opдер на обшук;

2) analogues: police photographic composites - фоторобот, sex offenders - збоченщіi;

3) explanation: a line-up identification - прочедурі безпосереднього упізнання, the тиg-shot evidence - ідентифікація за фотографією, waiver - офіиійна відмова від права зберігати мовчання і права на присутність адвоката. It should be noted that the translator used this method quite carefully, because explanatory translation violates such a requirement for terms as conciseness.

4) transformations (addition): holding cell -камери попереднього утримання.

It is worth noting that sometimes the translator intentionally reproduces a common word from the source text with a term in the target text: expert експерт-дактилоскопіст.

A small number of legal terms in the novel «Hearts of Three» by $\mathrm{D}$. London emphasizes the versatility of the novel:

... Senor Torres paused in eloquent inability to describe more definitely, and Thomas Regan, hard man used to dealing with hard men, proceeded to bore into him and his data like a cross-examining criminal lawyer / Сеньйор Торес замовк: йому бракувало слів, аби висловитися переконливіше, але Ріган, крута і тверда людина, яка звикла мати справу з людьми такого ж складу, як і він сам, почав витягати з нього все, ніби адвокат, що веде перехресний допит.

...Much more he admitted under the rapid-fire interrogation/ I me багато чого іншого змушений був визнати Альварес Торес під швидким вогнем допиту.

...Some little business that presses - how shall I say? - an insignificant little lawsuit that must be settled first / У мене тут одна невідкладна 
справа... як би ие сказати?.. невеликий судовий процес, який мені треба довести до кіния.

In the next sentence there are four terms within one sentence: .... Judges and lawyers engage in competitions and affrays of wit and learning, quite forgetting the plaintiffs and defendants, before them and paying them, who are seeking equity and justice and not wit and learning / Судді й адвокати мудрують, змагаючись один з одним у спритності розуму, вихваляються своєю вченістю $i$ зовсім забувають про позивачів $\boldsymbol{i}$ відповідачів, котрі платять їм $i$ чекають від них не спритності $i$ вченості, $a$ безпристрасності і справедливості.

It is worth saying the term lawyer in the meaning of «адвокат» is an Americanism, in $\mathrm{BrE}$ адвокат is translated as «barrister».

The novel «The Sellout» represents Afro-American modern literature. P. Beatty uses some juridical terms in it. Sometimes a passage in the novel can be stuffed with them. That use of legal terms within one paragraph creates a comic effect: the protagonist is not tried for these heinous crimes:

...Not Guilty-Murder. Not Guilty-DUI. Not Guilty-Assault of a Police Officer. Not Guilty-Sexual Abuse. Not Guilty-Child Abuse. Not Guilty-Elderly Abuse. Dismissed-Theft. Dismissed-Forgery. Dismissed-Domestic Violence (more than one thousand cases). Dismissed-Sexual Conduct with a Minor. Dismissed-48 Involving a Child in Drug Activity. Dismissed-Kidnapping...»/ Перш за все слід звернути увагу на те, шьо перекладач міняє місиями злочини та вердікти: Убивство - невинний. Розпусні дї - невинний. Знущання з дитини - невинний. Знущання з літньої людини - невинний. Крадіжка - звинувачення знято. Підробка - звинувачення знято. Домашнє насилля - звинувачення знято. Сексуальні дії з неповнолітньою особою -звинувачення знято. Залучення дитини до вживання наркотиків - звинувачення знято. Викрадення - звинувачення знято. All the terms have a dictionary equivalent and cause no difficulties except the one: DUI. DUI (Driving Under the Influence) has a meaning «the crime of driving after you have taken drugs or drunk too much alcohol». But in the Ukrainian translation it has a meaning «розпусні дії» (lecherous actions) and does not correlate to an original sense.

Summing up our paper, we can conclude that the range of problems in American literature causes usage of juridical terms in it. Stylistically they perform a tragic effect, however, they can create a comic coloring. The juridical terms are mainly translated into Ukrainian with the dictionary equivalent, though the translators can apply a contextual translation. The choice depends on stylistic and pragmatic aspects. 


\title{
References:
}

1. Білозерська Л. П. Термінологія та переклад / Л. П. Білозерська, Н. В. Возненко, С. В. Радецька. Вінниця : Нова Книга. 2010. 232 с.

2. Буянова Л. Ю. Термин как единица логоса. Москва : ФЛИНТА. 2012. $224 \mathrm{c}$.

3. Карабан В.I. Переклад англомовної наукової i технічної літератури. Граматичні труднощі, лексичні, термінологічні та жанровостилістичні проблеми. Вінниця. 2004. 576 с.

4. L'Homme, M. What is a term? Lexical Semantics for Terminology. Netherlands: Amsterdam: Benjamins Publishing Company, 2020. Pp. 55-78.

DOI https://doi.org/10.30525/978-9934-26-110-7-65

\section{ВИКОРИСТАННЯ ЛЕКСИКО-ГРАМАТИЧНИХ ТРАНСФОРМАЦІЙ ПРИ ПЕРЕКЛАДІ НІМЕЦЬКИХ КОМПОЗИТІВ УКРАЇНСЬКОЮ МОВОЮ}

\author{
Редчиць Т. В. \\ кандидат філологічних наук, \\ дочент кафедри прикладної лінгвістики та перекладу \\ Черкаський державний технологічний університет \\ м. Черкаси, Украӥна
}

Словотвір є основним способом поповнення словникового складу німецької мови. Відсутність словникових відповідників для великої кількості складних слів вимагає докладного аналізу їх перекладу на українську мову та призводить до необхідності дослідження способів передачі композитів на українську мову.

Особливість словотвору німецької мови дала поштовх до комплексного дослідження науковцями цієї галузі науки, оскільки кожна мова має свою унікальну структуру та певні особливості. Характерна особливість німецької мови, що відрізняе ії від інших мов - це велика кількість складних слів.

Питанням словотвору німецької мови займалися такі лінгвісти, як К. Райс, Т. Шіппан, В. Фляйшер, М. Д. Степанова, О. О. Селіванова, Л. А. Ковбасюк, Т. Ф. Сфремова, Г. І. Артемчук, Ш. Р. Басиров, та інші.

Одним 3 найбільш продуктивних способів збагачення словникового фонду мови вважається деривація. Деривація займається вивченням компонентів, з яких складаються складні чи похідні слова, досліджує 